\title{
Present Situation and Restricting Factors of Chinese Garlic Export to ASEAN
}

\author{
Xiangli Kong, Pei Zhang, Junnan Dong \\ Shaanxi Normal University International Business School \\ Xi'an, China \\ E-mail:1321063493@qq.com
}

\begin{abstract}
With the establishment of the China-ASEAN free trade zone, the trade in agricultural products, especially garlic, between China and ASEAN countries has developed rapidly. While both sides are engaged in mutually beneficial and win-win garlic trade, the problem of garlic trade has become increasingly prominent. First of all, this paper describes the rapid development of China's garlic export to ASEAN in recent years in terms of trade patterns and commodity structure of garlic exports. Then, it concludes that the factors restricting the further development of China's garlic export to ASEAN are unbalanced production and marketing, low scientific and technological level, low quality, lack of brand awareness, and serious anti-dumping. Finally, from the management mode of garlic export enterprises, the market and the garlic profession association, three countermeasures are put forward in this paper.
\end{abstract}

Keywords-Garlic Export; China-ASEAN Free Trade Zone; Current Situation; Restricting Factors

\section{INTRODUCTION}

\section{A. Research purpose and significance}

\section{1) Research purpose}

Garlic, as an important subdivision of agricultural trade between China and ASEAN, is a typical trade cooperation between China and ASEAN. With the implementation of zero tariff on January 1, 2010, China-ASEAN Free Trade area and agricultural products, the cooperation of garlic trade between the two sides is closer. However, the problems existing in the garlic trade between the two sides can not be ignored. This paper analyzes the current situation of garlic trade between the two sides, sums up the restrictive factors existing in the bilateral trade, and better carries out the garlic trade between the two sides. Deepening cooperation has certain enlightening effect.

\section{2) Significance}

With the establishment of the Free Trade Zone, China's average tariff on ASEAN dropped from 9.8 percent to 0.1 percent, and in 2015 China achieved zero tariffs on 90 percent of products in Vietnam, Laos, Cambodia and Myanmar. Coupled with the rapid development of the Internet and the international logistics system, at the same time the government encourages scientific and technological innovation, deepens cooperation on China's garlic exports with ASEAN, optimizes the industrial structure of garlic, and improves the quality of garlic. To deal with trade barriers and other aspects to provide inspiration and reference.

\section{B. A review of domestic and foreign studies}

According to the research literature of garlic export between China and ASEAN, it mainly focuses on garlic competitiveness, garlic price fluctuation, garlic industrial structure and trade barriers encountered by garlic export. In terms of garlic competitiveness, Boyle thinks that production cost and some productivity indicators are important indicators of competitiveness potential [1]. Liu Ling, Zhang Ying, Feng Jianhua and others think Chinese garlic is of good quality and International Market Garlic has a low trade cost and competitive advantage, but garlic exports are still primary products, garlic prices are low, resulting in low competitiveness [2]. Shuai Chuanmin believes that the export structure of garlic in China is not excellent and the single market structure is the main factor restricting the improvement of Chinese garlic export competitiveness [3]. In the aspect of garlic price fluctuation, Feng Juan and Zhang Shengyong discussed the factors influencing garlic export income from domestic and international aspects by constructing error correction model and CMS model, and concluded that the instability of export income led to garlic price fluctuation. With regard to the industrial structure of garlic, Gong Fengtao thinks that it is possible to expand garlic production. ChinaASEAN garlic trade structure should be improved by optimizing garlic industrial structure and giving play to the comparative advantage of garlic export in China. With regard to trade barriers to garlic exports, Pan Weiguang believes that China's low-cost advantage in agricultural exports to ASEAN will continue to be maintained, but if we want to turn the low price advantage into a competitive advantage, we need to break through the trade barriers of ASEAN countries [4]. Li Wenting believes that the key to green trade barriers is to strengthen environmental legislation to bring domestic production standards close to international standards [5]

These academic achievements, on the one hand, can not be used for reference in this paper because of the earlier data year. On the other hand, the existing research on garlic export at home and abroad mainly focuses on the specific garlic production areas in China to analyze. More research results have been formed. Based on the data collection in recent years and the analysis of ASEAN market, this paper comprehensively describes the current situation, restrictive 
factors and countermeasures of China's exports to ASEAN garlic.

\section{CURRENT SITUATION OF GARLIC TRADE BETWEEN CHINA AND ASEAN}

A. Exports are dominated by general trade and supplemented by small border trade

In terms of trade mode, China's garlic export trade to ASEAN countries mainly includes border small trade, general

Table 1 China's garlic export to ASEAN

\begin{tabular}{|c|c|c|c|c|}
\hline \multirow{2}{*}{ trade method } & \multicolumn{2}{|c|}{2007} & \multicolumn{2}{c|}{2008} \\
\cline { 2 - 5 } & Export quantity & Export value & Export quantity & Export value \\
\hline general trade & 140.36 & 1026.57 & 151.61 & 719.42 \\
\hline processing trade & 1.10 & 14.22 & 1.10 & 12.48 \\
\hline Border small trade & 15.82 & 10.04 & 16.01 & 48.07 \\
\hline Other trade & 0.02 & 0.08 & 0.03 & 0.12 \\
\hline
\end{tabular}

Source: http://www.mofcom .gov.cn/

\section{B. The Commodity structure of garlic export from China to ASEAN}

The export quantity and export amount of fresh garlic is the largest in China's export structure to ASEAN garlic. In 2007, the export amount of fresh garlic still reached 85.3 million US dollars, despite the declining trend of China's total garlic export in 2007. In 2015, the export volume of preserved garlic was 1734.6 kilotons, that of salted garlic was 11.7 kilotons in 2015, and that of dried garlic was 185.5 kilotons. The lowest annual export is frozen garlic, which was exported from 2007 in 2008, when China's garlic export suffered a serious setback. The US $\$ 198$ thousand in 2008 rose to US $\$ 656$ thousand in the year.

\section{CHINA'S RESTRICTING FACTORS ON THE DEVELOPMENT OF GARLIC TRADE IN ASEAN}

\section{A. The price fluctuates greatly, and the production and marketing are out of balance}

In 2009-2010, garlic prices continued to rise, "garlic you ruthless" force, appeared "vegetables more expensive than meat" phenomenon. As of July 2010, the cumulative gain reached $24.8 \%$, and you can see from figure 1 that garlic prices fluctuated and fluctuated from 2010 to 2012. Garlic prices violate the law of value and break away from the cost price, which highlights the lack of pricing of agricultural products in China. In addition, most of our garlic exporting enterprises deeply study and grasp the ASEAN market as a whole.

\section{B. Garlic products processing at the low scientific and technological level}

The garlic production enterprises in our country lag behind in developing ideas, lack investment of funds and scientific and technological talents, and lack technical training for garlic farmers, which makes garlic production inefficient. Seriously hindered the garlic production from the traditional extensive to modern intensive transformation. The high proportion of trade and processing trade. Statistics from the Foreign Trade Department of the Ministry of Commerce of China (see Table 2). 


\section{COUNTERMEASURES FOR THE PROMOTION OF GARLIC TRADE BETWEEN CHINA ANDASEAN}

\section{A. Coordinate garlic prices and maintain market order}

Give full play to the role of the garlic industry association, do a good job in researching the ASEAN market, collecting price information and the policy changes of major ASEAN countries, and doing a good job in price early warning and the long-term prediction of garlic prices, so as to reduce blindness. Increase effectiveness. It includes the information on the demand for garlic in ASEAN countries, the import policy of garlic in ASEAN countries and the price information on the international market. The garlic trade association can also carry on the centralized sale, which can effectively reduce the pressure price of the middleman, play the role of coordinating the garlic price, reducing the market risk and promoting the sale of garlic products of its members.

\section{B. Increase scientific research investment and the added value of garlic products}

In order to improve the added value of garlic industry, we should establish an innovative industrial department for deep processing of garlic, deepen the reform of garlic science and technology system, and focus on the development of high-tech industries such as garlic oil processing, garlic biological health care, garlic biomedicine and so on. Introduce and develop garlic high-tech, strengthen the development and application of garlic processing depth, storage, preservation and other related technologies, develop technology-intensive garlic industry, select high level, advanced means, knowledge intensive achievements.

\section{Implement garlic standardization production and optimize garlic quality structure}

It is an inevitable way to optimize the production structure of garlic to carry out the standardized production of garlic to promote the specialization, modernization and scale of garlic industry. To improve the quality of garlic products, strict control should be carried out from the source of garlic production. It is necessary to speed up the formulation and implementation of garlic technical regulations and qualified evaluation programs, and to eliminate the low quality garlic products. Establish the garlic production standardization demonstration base, use the example strength to deepen the understanding to the garlic standardization production, set up the brand effect with the standardized production and the propaganda in place.

\section{Improve the degree of organization of garlic and create famous international brands}

The development of garlic enterprise specialized cooperative can change the weak position of individual enterprise in the export market and play an important role in ensuring the benefit of garlic exporter and activating the market. It can not only stimulate the productive enthusiasm of garlic farmers, but also accumulate the original small and scattered garlic enterprises, strengthen the leading garlic export enterprises, and promote the management way of "leading enterprises exporting garlic farmers," Forming a one- stop service system with industrial chain, creating the main body of garlic export with world influence brand, actively taking the initiative in the market competition, seizing the opportunity and responding to the challenge.

\section{CONCLUSION}

Through the analysis of this paper, we can find that China's exports to ASEAN garlic have developed rapidly in recent years in terms of export volume, trade mode and commodity structure of garlic export. The factors that restrict the further development of China's garlic export to ASEAN are the imbalance of production and marketing, low science and technology content, low quality, lack of brand awareness and serious antidumping. Finally, the countermeasures to promote the export of Chinese garlic to ASEAN are put forward. Garlic is one of the important agricultural products that China exports to ASEAN in recent years. Today, when the world economy is deeply adjusted, garlic faces the key period of new and old production capacity conversion. With the China-ASEAN Free Trade area, "Belt and Road" "the establishment of China's comprehensive national strength, especially the enhancement of its strength of scientific and technological innovation, has brought new opportunities for the garlic trade cooperation and exchange between China and ASEAN countries.

\section{REFERENCES}

[1] Zhang Hua. Comparative advantage, competitive advantage and International Competitiveness [J]. Economic problems, 1999(04):9.

[2] Liu Xuezhong, Gu Ming Mei, Li Zhonghua. Problems and Countermeasures to further expand the export of garlic in China [J]. agricultural economy, 2007(12):68.

[3] Shuai Chuanmin, Cheng Guoqiang, Zhang Jinlong. An estimate of the International Competitiveness of Chinese Agricultural products [J]. Managing the world, 2003(01):97.

[4] Mr Poon Wai-kwong. Analysis of the causes and Countermeasures of Technical barriers to Trade in China's Agricultural products Export [J]. International trade issues, 2003(07):25.

[5] Shan Yadong. Study on the influence of Green Barrier on China's Agricultural products Export and its Countermeasures [J]. Journal of Wuhan training Institute of Agricultural Bank of China, 2008(04):59.

[6] Qu Yu Jun. Study on trade competitiveness of agricultural products in Central China [M]. Changsha: Central South University press, 2015.175176.

[7] Lu Yuhua, Zhang Liuwei. A study on China's garlic Export Trade [J]. Agricultural economy, 2011(02):93.

[8] Zhang Jiguo. Study on the situation and Development of garlic Export in China [J]. Agricultural economic problems, 2009(09):99. 